\title{
STATINS-INDUCED HEPATOTOXICITY IN ALBINO RATS: A COMPARATIVE STUDY BETWEEN ATORVASTATIN AND SIMVASTATIN
}

\author{
Mohamed Adly; Ahmed Elshatory; Hanaa Elzahed; George N.B. Morcos*, \\ Ehab Refaat Ibrahim**; Walaa Awad*** \\ Department of Forensic Medicine and Clinical Toxicology, Faculty of Medicine, Cairo \\ University \\ *Department of Medical Biochemistry \& Molecular Biology, Faculty of Medicine, Cairo \\ University \\ ** Department of Histology, Faculty of Medicine, Cairo University \\ ***Clinical Pharmacy, Almoalmean Hospital
}

Mohamed Adly Mohamed

Tel.: 01223462419 - 01112611621

e-mail: mohamedadly466@gmail.com

\begin{abstract}
Objective: This experimental study aimed to evaluate the statin-induced hepatotoxicity in albino rats, as well as to compare the potential hepatotoxicity between atorvastatin and simavastatin through evaluation of both biochemical and histopathological parameters. Materials \& Methods: 60 male albino rats were used in this study and were equally divided into three groups. The control group received only saline orally, the atorvastatin group which received (80 $\mathrm{mg} / \mathrm{kg})$ orally, and the simavastatin group which received simavastatin $(80 \mathrm{mg} / \mathrm{kg})$ orally. The study was conducted over a period of 12 weeks and at the end blood samples and liver tissues were obtained for assessment of biochemical markers of the liver and histopathological examination. Results: All the biochemical parameters in the current study showed higher values in the atorvastatin and simvastatin groups compared to the control group with significant probability value. The significance was detected between each of the statin groups and the control group. However no significant difference was found between atorvastatin and simvastatin group. Likewise, histopathological results showed significant hepatic injury in case of both statin groups compared to the control one. Conclusion \& Recommendations: Atorvastatin and simvastatin induced hepatic injury as demonstrated by both biochemical and histopathological results in this study. Moreover, no significant difference was found between atorvastatin and simvastatin as regard statin induced liver injury.
\end{abstract}

KEYWORDS: statins, atorvastatin, simvastatin, hepatotoxicity. 


\section{INTRODUCTION}

Drug induced liver injury (DILI) refers to liver affection which is usually due to an adverse reaction caused by drugs administration or dietary supplements. DILI generally is considered as a significant cause of potentially severe acute and chronic liver affection (Fontana et al., 2010).

Among the most commonly and widely used drugs all over the world to lower the blood cholesterol levels are statins. Some adverse effects may present with the use of statins despite that they are considered as well tolerated drugs (Björnsson et al., 2013). Myopathy, increased incidence of diabetes and increased levels of serum transaminases are among the most common reported adverse effects of statins (Desai et al., 2014).

Patients with high cholesterol levels are more liable to develop severe vascular and cardiac diseases. These patients are usually prescribed atorvastatin, simvastatin or another one of the statin drugs at a high dose. Usually atorvastatin is the most commonly described drug in such case. This is attributed to the more effective potential of atorvastaatin than simvastatin at lowering blood cholesterol levels (Nawrocki et al., 1995; and Jones et al., 1998).

Many investigations have recently focused on the relationship between the dose of statins and statin-induced liver injury (SILI). It has been stated that high doses of statins can easily participate in induction of liver damage more than lower doses of statins (Kasliwal et al., 2007; and Chen et al., 2014).
It has been postulated that elevation of serum transaminases is the most common liver affection associated with statins. Furthermore, statin-induced elevation of liver enzymes usually occurs within the first three to twelve months after introduction of therapy (Björnsson et al., 2012; and Perdices et al., 2014).

\section{MATERIALS \& METHODS}

\section{- Experimental condition}

All the experimental animals used in this study received humane care according to the guidelines outlined in the "Guide for the Care and Use of Laboratory Animals" by the National Institute of Health (NIH). The experimental protocol for the use of live animals in this study was approved by Louisiana State University Institutional Animal Care and Use Committee.

Sixty male, albino rats, weighing of 180-200 gm aged 3 months were provided from animal laboratory and used in this experiment. All animals maintained at a constant temperature (25 $+/-3{ }^{\circ} \mathrm{C}$ ) in a controlled room in which a light/dark cycle was maintained. All the rats had free access to water and were fed with standard commercial chow diet. After 7 days of acclimatization, the animals were distributed randomly into three groups each consisted of twenty rats:

I. The control group: rats in this group received physiological saline by oral gavage for 12 weeks.

II. Atorvastatin group: rats in this group received atorvastatin 80 $\mathrm{mg} /$ kilogram $(\mathrm{kg})$ dissolved in distilled water by oral gavage for 12 weeks. 
III. Simvastatin group: rats in this group received simavastatin $80 \mathrm{mg} / \mathrm{kg}$ dissolved in distilled water by oral gavage for 12 weeks.

At the end of the eighth week, all the experimental rats were anesthetized and euthanized by decapitation. Blood samples were collected for estimation of biochemical parameters and the liver was quickly removed and fixed in $10 \%$ neutral formalin solution for histopathological examinations.

- Biochemical analysis

1. Aspartate transaminase (AST) and alanine transaminase (ALT) activities are determined according to the method of Reitman and Frankel (1957).

2. Alkaline phosphatase (ALP) activity is determined according to the method of Babson et al. (1966).

3. Estimation of total serum bilirubin was determined by colorimetric methods using commercial kits (DiaSysHolzheim, Germany), on a semiautomatic clinical chemistry analyser.

- Histopathological analysis

Liver tissue samples were fixed in $10 \%$ buffered formalin, embedded in paraffin and then cut at 4-5 microns thickness. The cut sections were then stained with hematoxylin and eosin (HE) to be examined by light microscopy. Histopathological changes were diagnosed in a blinded manner by a specialized pathologist unaware of the study groups.

- Statistical analysis

The collected data were tabulated and analyzed using SPSS version 22 soft ware (SPSS Inc, Chicago, ILL Company). Categorical data were presented as number and percentages while quantitative data were expressed as mean \pm standard deviation. Fisher's exact test and ANOVA was used as tests of significance. Significant ANOVA were followed by post -hoc test to detect significant pairs. The accepted level of significance in this work was stated at $0.05 \quad(\mathrm{P} \quad<0.05$ was considered significant).

\section{RESULTS}

- Biochemical results

The mean value \pm SD for the total serum bilirubin in the control group was 1.2.5 \pm 0.12 while in the atorvastatin and simvastatin groups, it was $1.5 \pm 0.4$ \& $1.5 \pm 0.3$ respectively. The probability value was found highly significant $(\mathrm{P}=$ 0.004). This significance was further studied by post-hoc test and the significance was found between each of atorvastatin \& simvastatin groups on one hand and the control group on the other hand $(\mathrm{P}=0.005$ and 0.03 respectively) as shown in table 1.

The mean value \pm SD for the serum aspartate transaminase (AST) activity in the control group was $70.8 \pm 8.4$ while in the atorvastatin and simvastatin groups, it was $122.2 \pm 60.4 \quad \& \quad 111 \pm 57.9$ respectively. The probability value was found highly significant $(\mathrm{P}=0.003)$ and this significance was further studied by post-hoc test. The significance was found between atorvastatin group and control group $(\mathrm{P}=0.003)$ and also between simvastatin group and the control group $(\mathrm{P}=0.02)$ as shown in table 2 .

As for the serum alanine transaminase (ALT) activity, the mean value $\pm \mathrm{SD}$ for the control group was 56.5 \pm 7.9. While it was $95.7 \pm 36.7$ for atrovastatin group and $86.2 \pm 30.9$ for simvastatin group. The probability value was found highly significant $(\mathrm{P}=0.000)$. 
This significance was further studied by post-hoc test. The significance was found between atorvastatin group and control group $(\mathrm{P}=0.000)$ and also between simvastatin group and the control group $(\mathrm{P}=0.001)$ as shown in table 3.

Furthermore, the serum alkaline phosphatase (ALP) activity showed $93.8 \pm 7$ as a mean value \pm SD. Atovastatin group has a mean value \pm SD of $156.5 \pm 74.7$ compared to simvastatin group which has $136.2 \pm 61.6$ as a mean value $\pm S D$. The probability value was found highly significant $(\mathrm{P}=0.003)$. This significance was further studied by posthoc test while revealed a significance between atorvastatin group and control group $(\mathrm{P}=0.004)$ and also between simvastatin group and the control group $(\mathrm{P}=0.02)$ as shown in table 4 .

- Histopathological results

Examination of the liver tissue sections in the control revealed that all the cases i.e. 20 samples showed normal hepatic structure. As for the cases treated with atorvastatin, 4 cases $(25 \%)$ showed hepatocellular injury, 2 cases (10\%) showed cholestatic injury of the liver while one case only showed mixed hepatocellular and cholestatic hepatic injury $(5 \%)$. On the other hand, cases treated with simvastatin were associated with 4 cases $(20 \%)$ with hepatocellular injury, one case $(5 \%)$ with cholestatic hepatic injury and also one case (5\%) with mixed hepatocellular and cholestatic hepatic injury. The probability was found highly significant $(\mathrm{P}<0.007)$ between the control group and both atorvastatin \& simvastatin groups. (table5).

Table1: Mean values \pm SD of total serum bilirubin

\begin{tabular}{||l|l|l|l|}
\hline Total biliburbin level & Mean \pm S.D & F test & P value \\
\hline \hline Control group (20) & $1.2 .5 \pm 0.12$ & 6.2 & $0.004^{*}$ \\
\cline { 1 - 2 } Atorvastatin (20) & $1.5 \pm 0.4^{* *}$ & & \\
\cline { 1 - 2 } Simvastatin (20) & $1.5 \pm 0.3 \#$ & & \\
\hline
\end{tabular}

*(HS) highly significant results.

$* * \mathrm{P}$ value $=0.005$ vs control group $\& \# \mathrm{P}$ value $=0.03$ vs control group (using Bnferroni post hoc test $)$ 
Table 2: Mean values \pm SD of Aspartate transaminase (AST) enzyme activity

\begin{tabular}{||c|c|c|c||}
\hline AST Enzyme level & Mean \pm S.D & F test & P value \\
\hline \hline Control group (20) & $70.8 \pm 8.4$ & 6.3 & $0.003^{*}$ \\
\hline Atorvastatin (20) & $122.2 \pm 60.4 * *$ & & \\
\hline Simvastatin (20) & $111 \pm 57.9 \#$ & & \\
\hline
\end{tabular}

$* * \mathrm{P}$ value $=0.003$ vs Group1 $\&$ \#P value $=0.02$ vs Group1 (using Games Howell post hoc test)

Table 3: Mean values \pm SD of Alanine transaminase (ALT) enzyme activity

\begin{tabular}{|c|c|c|c|}
\hline ALT Enzyme level & Mean \pm S.D & F test & P value \\
\hline Control group (20) & $56.5 \pm 7.9$ & \multirow[t]{3}{*}{10.6} & \multirow[t]{3}{*}{$0.000^{*}$} \\
\hline Atorvastatin (20) & $95.7 \pm 36.7 * *$ & & \\
\hline Simvastatin (20) & $86.2 \pm 30.9 \#$ & & \\
\hline
\end{tabular}

${ }^{* *} \mathrm{P}$ value $=0.000$ vs Group1 \& $\# \mathrm{P}$ value $={ }^{0.001}$ vs Group1 (using Games Howell post hoc test)

Table 4: Mean values \pm SD of alkaline phosphatase (ALP) activity

\begin{tabular}{|c|c|c|c|}
\hline ALP Enzyme level & Mean \pm S.D & F test & P value \\
\hline \hline Control group (20) & $93.8 \pm 7$ & 6.4 & $0.003^{*}$ \\
\hline Atorvastatin (20) & $156.5 \pm 74.7 * *$ & & \\
\cline { 1 - 2 } Simvastatin (20) & $136.2 \pm 61.6 \#$ & & \\
\hline
\end{tabular}

*(HS) highly significant results.

**P value $=0.004$ vs Group1\& \#P value $=0.02$ vs Group1 (using Games Howell post hoc test) 
Table 5: percentage of different types of hepatic injury in the different groups

\begin{tabular}{|c|c|c|c|c|c|}
\hline $\begin{array}{c}\text { Histopathological } \\
\text { Results } \\
\text { Groups }\end{array}$ & Hepatocellular & Cholestatic & Mixed & None & $\begin{array}{c}\left(\mathrm{X}^{2}\right) \\
\text { P value }\end{array}$ \\
\cline { 1 - 4 } $\begin{array}{c}\text { Control group } \\
(20)\end{array}$ & 0 & 0 & 0 & $20(100 \%)$ & \\
\cline { 1 - 4 } $\begin{array}{c}\text { Atorvastatin } \\
\text { group (20) }\end{array}$ & $5(25 \%)$ & $2(10 \%)$ & $1(5 \%)$ & $12(60 \%)$ & $\begin{array}{c}9.7 \\
(0.007)^{*}\end{array}$ \\
\cline { 1 - 3 } $\begin{array}{c}\text { Simvastatin } \\
\text { group (20) }\end{array}$ & $4(20 \%)$ & $1(5 \%)$ & $1(5 \%)$ & $14(70 \%)$ & \\
\hline
\end{tabular}

*P = highly significant

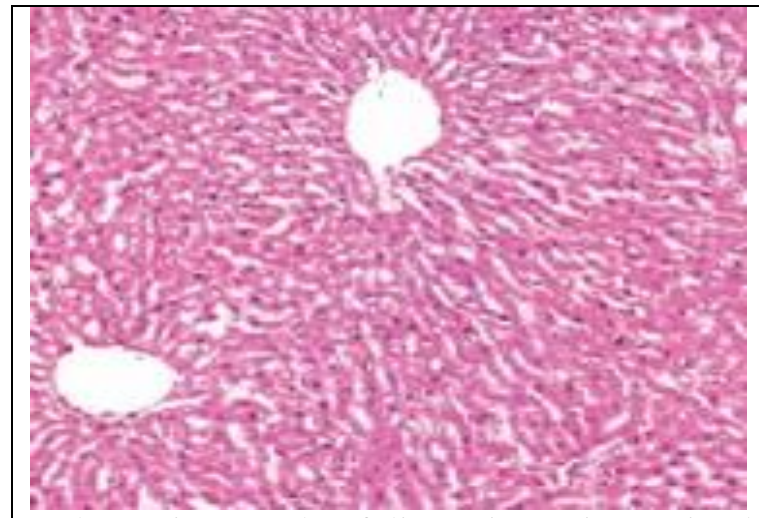

(Photomicrograph of liver tissue in (stained with $H \& E X$ 100) showing normal renal tissue). Representing $100 \%$ of control group; $60 \%$ of atorvastatin group, and $70 \%$ of simvastatin group.

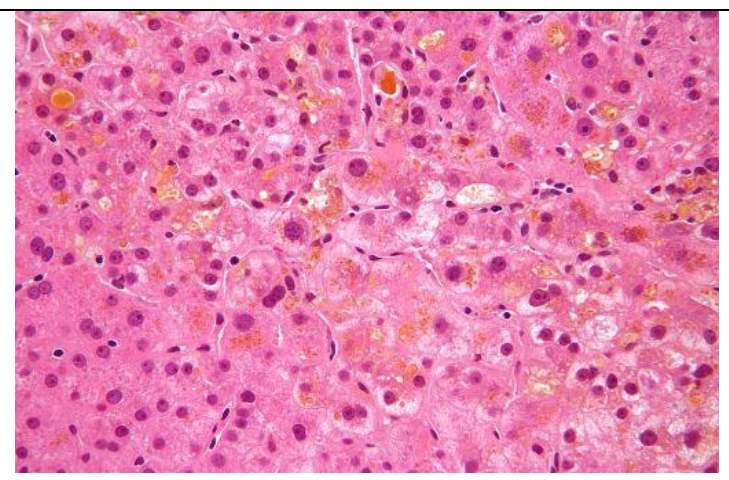

(Photomicrograph of liver tissue in (stained with H\&E $X$ 200) showing cholestasis. Representing $10 \%$ of atorvastatin group and $5 \%$ of simvastatin group.

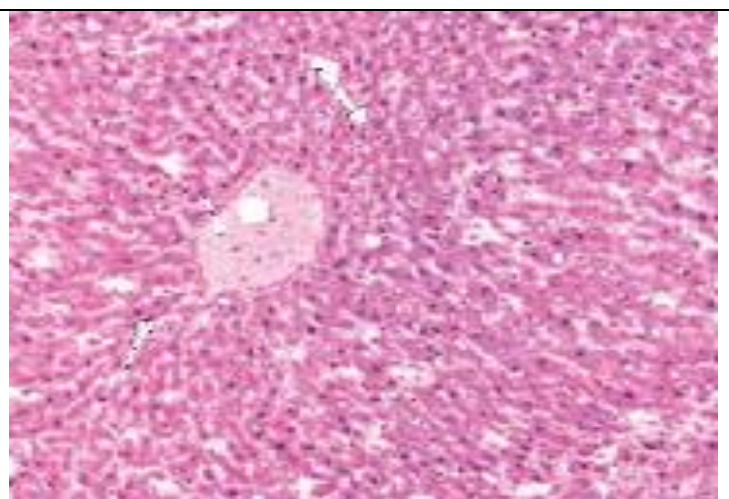

(Photomicrograph of liver tissue in (stained with $H \& E X$ 100) showing hepatocellular damage with cellular infiltration and sinusoidal congestion. Representing $25 \%$ of atorvastin group and $20 \%$ of simvastatin group.

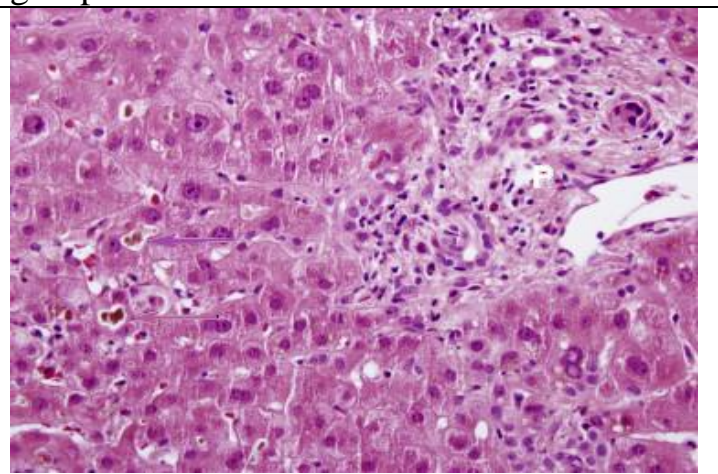

(Photomicrograph of liver tissue in (stained with H\&E X 200) showing mixed cholestasis and hepatocellular damage Representing 5\% of atorvastatin group and 5\% of simvastatin group. 


\section{DISCUSSION}

High blood level of cholesterol is associated with increased risk of cardiovascular diseases. Among the drugs that effectively reduce blood cholesterol levels and cardiovascular risk are statins. Statins are regarded nowadays as a cornerstone for prevention of cardiovascular diseases in a wide range of patients (Baigent et al., 2010).

However, the use of statins is limited by its adverse effects in many patients and sometimes discontinuation of statins is considered in some patients. Myopathy which may be associated with muscle complaints and increased muscle enzymes has been recorded (Guyton et al., 2014; and Rosenson et al., 2014). Other adverse effects include neurological affection and diabetogenic effects (Stulc \& Ceska, 2014).

However, the most serious effect of statin administration is SILI which is commonly manifested as elevation of liver transaminases that can be associated with hepatocellular injury, cholestatic liver injury or mixed liver injury i.e. combined hepatocellular and cholestatic liver damage (Kasliwal et al., 2007; and Chen et al., 2014).

It has been reported that statins induce elevation of the hepatic liver enzymes that can be used to monitor SILI. The statin-induced elevation of serum hepatic transaminases and serum alkaline phosphatase enzymes usually occurs within the first three to twelve months after introduction of statin therapy (Björnsson et al., 2012; and Russo et al., 2014).
All the biochemical parameters in this study such as total serum bilirubin, serum aspartate transaminase activity, serum alanine transaminase, and serum alkaline phosphatase activity exhibited a higher significant values in the both atorvastatin and simvastatin groups compared to the control group denoting that statins drugs are associated with hepatic injury. These results were in concordance with the study carried by Emilia et al., 2014 which described similar results and moreover stated that statins accounted for $5.5 \%$ of hepatotoxicity in the Spanish hepatotoxicity registry. In addition, Schwartz et al., 2001 showed that abnormal liver transaminases which were three times the upper limit of normal were more common in the atorvastatin group than in the control group. On the opposite side, several studies researched the efficacy and adverse effects of statins and have reported there efficacy and considered them as a safe drugs (Shepherd et al., 1995; and Pedersen et al., 2004).

Furthermore, the different biochemical parameters studied in the current study did not show a significant difference between both atorvastatin and simvastatin groups. Björnsson \& Olsson (2005) carried their research on drug-induced hepatic damage and reported that 8 cases are due to statins which were distributed equally between atorvastatin and simvastatin. On the other hand, the results in the current study are in contrast with Clarke et al., 2016 that stated that the risk of hepatotoxicity is higher in cases of atorvastatin than simvastatin.

As regard the histopathological results in the current study, both atorvastatin and simvasatatin groups 
were associated with significant hepatic damage compared to the control group. However, the incidence of hepatic injury was found greater in case of atorvastatin than simvastatin but the difference between the two studied groups was insignificant. These results were in agreement with Emilia et al., 2014 that stated that atorvastatin and simvastatin accounted for $34 \% \& 27.7 \%$ of the total SILI. In addition, Björnsson and Olsson, 2005 showed that the incidence of hepatic damage is equal between atorvastatin and simvastatin. On the opposite site, Clarke et al., 2016 showed that atrovastatin is associated with greater incidence of SILI than simvastatin. The incidence of SILI was $6.5 \%$ for high dose of atorvastatin while it was $1.3 \%$ for simvastatin.

In the current study, it was found that hepatocellular damage is the predominant liver injury in both atorvastatin and simvastatin groups. This result was in concordance with the study carried by Emilia et al., 2014 that described hepatocellular damage as the major hepatic injury in both atorvastatin and simvastatin. Moreover, similar results were reported by Wang et al., 2016 that demonstrated that hepatocellular damage is the predominant liver injury in SILI.

\section{CONCLUSION}

The present study demonstrated that statins are associated with a risk of hepatic injury as shown by both biochemical and histopathological results. However, no significant difference was found between either atorvastatin or simvastatin group.

\section{RECOMMENDATIONS}

- Further studies should be carried on the same atorvastatin and simvastatins but with a lower therapeutic dose $(40 \mathrm{mg} / \mathrm{kg})$ and the results should be compared with the current one.

- Similarly, other statin drugs such as lovastatin, paravastatin, rosuvastatin ... should be carefully examined for the potential of drug-induced hepatotoxicity.

- It is advised to evaluate statin induced liver injury in patients under treatment with statins after different intervals of administration.

\section{ACKNOWLEDGEMENT}

We would to express our deepest gratitude to Dr. Hala A. Abed lecturer of research and biostatistic at Public Health Department, Faculty of Medicine, Benha University for carrying the effort of the statistical analysis in this study.

\section{REFERENCES}

Fontana RJ, Seeff LB, Andrade RJ, Björnsson E, Day CP, Serrano J, et al. (2010) Standardization of nomenclature and causality assessment in drug-induced liver injury: Summary of a clinical research workshop. Hepatology; 52:730-42.

\section{Björnsson ES, Bergmann OM,} Björnsson HK, Kvaran RB, Olafsson S. (2013). Incidence, presentation, and outcomes in patients with drug-induced liver injury in the general population of Iceland. Gastroenterology; 144:

1419-25. 
Desai CS, Martin SS, Blumenthal RS. (2014). Non-cardiovascular effects associated with statins. Brit Med J.; 349:p 3743.

Jones P, Kafonek S, Laurora I, Hunninghake D. (1998). Comparative dose efficacy study of atorvastatin versus simvastatin, pravastatin, lovastatin and fluvastatin in patients with hypercholesterolemia [The CURVES Study]. Am J Cardiol.; 81:582-587.

Nawrocki JW. Weiss SR, Davidson MH, Sprecher DL, Schwartz SL, Lupien PJ, Jones PH, Haber HE, Black DM. (1995). Reduction of LDL cholesterol by $25 \%$ to $60 \%$ in patients with primary hypercholesterolemia by atorvastatin, a new HMG-CoA reductase inhibitor. Arterioscler Thromb Vasc Biol.; 15: 678-682.

Chen GL, Hsiao FY, Dong YH, Shen LJ, Wu FL. (2014). Statins and the risk of liver injury: a population-based case-control study. Pharmacoepidemiol Drug Saf; 23: 719-25.

Kasliwal R, Wilton LV, Cornelius V, Aurich-Barrera B, Shakir SA. Safety profile of rosuvastatin: results of a prescription-event monitoring study of 11,680 patients. Drug Saf 2007; 30: $157-$ 70.

\section{Björnsson E, Jacobsen EI, Kalaitzakis} E. (2012). Hepatotoxicity associated with statins: reports of idiosyncratic liver injury post-marketing. J Hepatol; 56: 374-80.
Perdices EV, Medina-Cáliz I, Hernando S, Ortega A, Martín-Ocaña F, Navarro JM. (2014). Hepatotoxicity associated with statin use: analysis of the cases included in the Spanish Hepatotoxicity Registry. Rev Esp Enferm Dig; 106: 246-54.

Reitman S, and Frankel S (1957): Colorimetric estimation of AST \& ALT activities. J. Lab. Chin. Med.; 28: 56 .

Babson, AL, Greeley SJ, Coleman CM, and Phillips 0E. (1966) Phenolphthalein mono- phosphate as a substrate for serum alkaline phosphatase. Clin. Chem.; 12, 482.

Baigent C, Blackwell L, Emberson J, Holland LE, Reith C, et al. (2010). Cholesterol Treatment Trialists' (CTT) Collaboration. Efficacy and safety of more intensive lowering of LDL cholesterol: a meta-analysis of data from 170,000 participants in 26 randomised trials. Lancet; 376 (9753):1670-81.

Guyton JR, Bays HE, Grundy SM, Jacobson TA (2014). The National Lipid Association Statin Intolerance Panel An assessment by the Statin Intolerance Panel. J Clin Lipidol. 2014; 8 (3 Suppl):S72-81.

Rosenson RS, Baker SK, Jacobson TA, Kopecky SL, Parker BA (2014). The National Lipid Association's Muscle Safety Expert Panel An assessment by the Statin Muscle Safety Task Force. J Clin Lipidol. 2014; 8 (3 Suppl):S58-71.

Stulc T, Ceska R. (2014). Statins, glycemia, and diabetes mellitus: 
another point of view. Curr Atheroscler Rep.; 16 (12):458.

Emilia V P, Inmaculada MedinaCáliz, Sofía H., Aida O., Francisca Martín-Ocaña, José M N, et al. (2014). Hepatotoxicity associated with statin use: Analysis of the cases included in the Spanish Hepatotoxicity Registry. Rev Esp Enferm Dig (Madrid). Vol. 106, N.؛ 4, pp. 246-254.

Clarke AT, Johnson PC, Hall GC, Ford I, Mills PR (2016). High Dose Atorvastatin Associated with Increased Risk of Significant Hepatotoxicity in Comparison to Simvastatin in UK GPRD Cohort. PLoS One. 2016 Mar 16; 11(3):e0151587.

Pedersen TR, Kjekshus J, Berg K, Haghfelt $T$, Faergeman $O$, Faergeman G, Pyörälä $\mathbf{K}$, Miettinen $\mathbf{T}$, Wilhelmsen $\mathbf{L}$, Olsson AG, Wedel H (2004). Randomised trial of choleste rol lowering in 4444 patients with c oronary heart disease: the Scandinavian Simvastatin Survi val Study (4S). 1994. Scandinavian SimvastatinSurvival S tudy Group. Atheroscler Suppl.; 5 (3):81-7.

Schwartz GG, Olsson AG, Ezekowitz MD, Ganz P, Oliver MF, Waters D, Zeiher A, Chaitman BR, Leslie S, Stern T (2001). Effects of atorvastatin on early recurrent ischemic events in acute coronary syndromes: the MIRACL study: a randomized controlled trial. JAMA; 4; 285 (13):1711-8.
Shepherd J, Cobbe SM, Ford I, Isles CG, Lorimer AR, MacFarlane PW, McKillop JH, Packard CJ (1995). Prevention of coronary heart disease with pravastatin in men with hypercholesterolemia. West of Scotland Coronary Prevention Study Group. N Engl J Med.; 16;333(20):1301-7.

Björnsson E, Olsson R. (2005), Outcome and prognostic markers in severe drug-induced liver disease. Hepatology.; 42 (2):481-9.

Russo MW, Hoofnagle JH, Gu J, Fontana RJ, Barnhart H, Kleiner DE (2014). Spectrum of statin hepatotoxicity: experience of the Drug-Induced Liver Injury Network. Hepatology; 60: 679-86.

Björnsson E, Jacobsen EI, Kalaitzakis E (2012). Hepatotoxicity associated with statins: reports of idiosyncratic liver injury post-marketing. J Hepatol; 56: 374-80.

Wang LY, Huang YS, Perng CL, Huang B, Lin HC (2016). Statin-induced liver injury in an area endemic for hepatitis B virus infection: risk factors and outcome analysis. Br J Clin Pharmacol.; Sep; 82(3): 823-830. 
الملخص العربى

التسمم الكبدى المصاحب لماده الاستاتين: دراسه مقارنه بين عقار الاتورفستاتين و السيمفستاتين

محمد عدلى، أحمد الشطورى، هناء الزاهد، جورج مرقص*، ايهاب رفعت ابراهيم**،، ولاء عوض****

قسم الطب الشرعى والسموم الاكلينيكيه كلية الطب جامعة القاهرة

قسم الكمياء الحيوية كلية الطب جامعة القاهرة*

قسم الهيستولوجيا كلية الطب جامعة القاهرة**

***** صياله اكلينكية مستثفى المعلمين

تعتبر مادة الاستاتين من اكثر المو اد شيو عا على مسنوى العالم فى علاج ارتفاع نسبه الكوليستيرول في الدم و علاج امر اض القلب و الاو عيه الدمويه إلا أن الآعر اض الجانبية لمادة الاستاتين تحد من استخدامها في كثير من الاحيان.

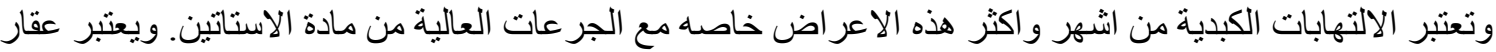
الاتورفتاتين من اكثر العقاقير فاعلية لقدرته الفائقه على تخفيض نسبة الكوليستيرول في الدئ الدئ ومن المتعارف عليه

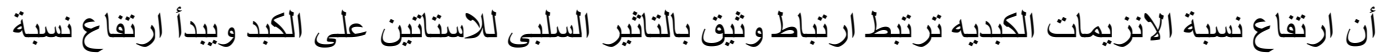

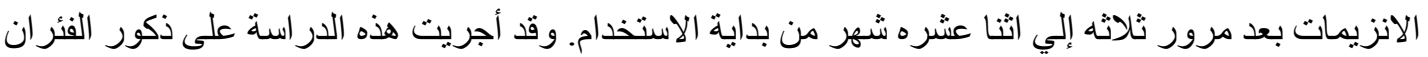

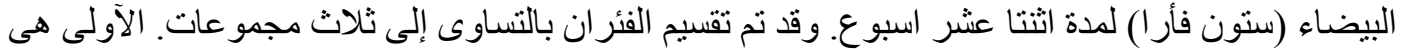

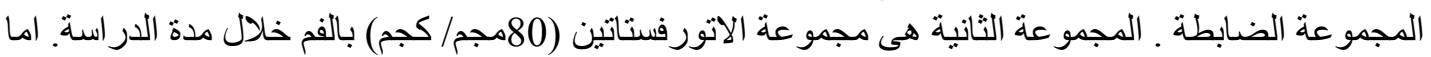
المجمو عة الثالثة فقد أعطيت السيمفستاتين (80مجم/ كجم) بالفم خلال مدة الدراسة. و تمت در اسة وظائف الكبد الكاند

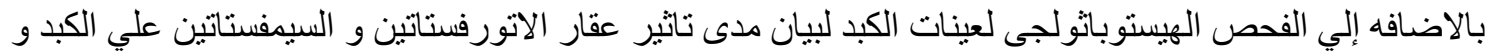

المقارنه بينهم. وقد اظهرت النتائج البيوكميائيه ارتفاع ذو دلاله احصائيه بين كل من مجمو عتي الاتورفستاتين و

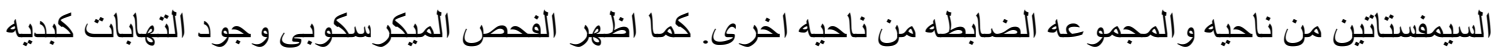
ناتجه عن تتاول عقار الاتورفتاتين و السيمفستاتين. إلا انه لم يلاحظ فرق ذو دلاله احصائيه بين كل من مجمو عتي الاتور فستاتين و السيمفستاتين. 